\title{
The Complexities of Regional Development Planning Reform: The Indonesian Case
}

\author{
Yeremias T. Keban`
}

\begin{abstract}
Development planning reform retains a significantly prominent position as it determines the success of development particularly in developing countries. However, implementing development planning reform is no easy feat as various obstacles ensue. This study was conducted in the Yogyakarta Province, Indonesia to identify these specific obstacles through a content analysis of regional development planning documents, provided along with the support of relevant literature study. The results of the study show that the obstacles encountered were quite complex, namely the low capacity of regional government, failure in implementing principles of good governance and bureaucratic reform, and the intensity of political elites' dominance in the region who utilize development planning as a means of achieving their interests. Affirmative policies to enhance regional capacity, to rearrange regulations and limit political party dominance, and to reconfigure the regional head's position as a political functionary and personnel administrator are thus recommended to address these issues.
\end{abstract}

\section{Keywords:}

strategic plan; good governance; bureaucratic reform; regional capacity

\section{Introduction}

Development planning is the planning of a series of process in order to achieve development goals (Potts et al., 2003). The relationship between planning and development is analogous to the relationship between means and ends, thus development failure tends to be associated with failure of planning. Development failures in various developing countries have urged governments to reevaluate existing planning and carry out planning reforms relating to the paradigm it follows for planning, or its substance, approach, and planning process. This is important as planning could become a problem instead of a solution (Turner \& Hulme, 1997).

The initiative of conducting development planning reform in Indonesia began to surface when the regional autonomy issue and decentralization discourse had increasingly intensified. The 1998 economic and political crisis had aggravated the domestic political climate and demanded decentralization be implemented (Forester, 1999), including decentralization of development planning, given that regional conditions in Indonesia were considered to vary in numerous aspects while centralization was deemed unresponsive to those conditions (Ranis \& Stewart, 1994), even more so with the unfair treatment afforded by the Indonesian government to regions outside of Java (Suwondo, 2002), as well as the rise of separatism sentiments in various regions throughout Indonesia (Fitriani, 2005).

Decentralization and regional autonomy was implemented in 2001 which initiated

\footnotetext{
- Department of Public Policy and Management, Faculty of Social and Political Sciences, Universitas Gadjah Mada Email: kebanjeremy@gmail.com
} 
the handing over of regional development planning matters that had been dominated by the central government to the regions, and thereby making it the regional governments' responsibility. Through Law No. 25/2004 on the Development Planning System, development planning reform was implemented and its operational procedures were subsequently regulated in the Minister of Home Affairs Regulation (Peraturan Menteri Dalam Negeri Permendagri) No. 54/2010, which was revised with Permendagri No. 86/2017. Some specific aspects stipulated in the reform among others are a change in planning approach, the use of strategic planning at the national, provincial, regional, and municipal levels, and the implementation of governance principles in the planning process.

The development planning reform was expected to become an actual solution in addressing the issues of regional development in Indonesia. However, the planning reform contained contents that were considered quite complicated, and it was formally carried out by bureaucratic institutions and apparatus that tended to be obstructive rather than accommodating (Turner \& Hulme, 1997), particularly given a specific context such as Indonesia. This is indeed an interesting topic that requires further in-depth analysis.

\section{Problem Identification}

The complexity of Indonesia's geographical factor as an extensive archipelagic state (Cribb \& Ford, 2009) should be wellacknowledged, and coupled with the diversity of its socio-cultural aspects and the varying levels of prosperity and economic advancement (Forshere, 2006; Hill \& Vidyattama, 2014), this certainly pose as a tremendous challenge for development. The capacity of regional government institutions and apparatus also varies from those that are highly competent and modern to those that are most precarious. This is also the case for communities living in urban and in rural areas. For advanced urban communities a more progressive, collaborative, participatory, and bottom-up method of development planning is more likely to be successfully implemented, yet for underdeveloped rural communities, they would have to resort to use conventional methods that tend to be top-down in their approach (Dalal-Cayton, et al., 2003).

It is interesting that the development planning reform, according to its mandate in Law No. 25/2004 and its implementing regulations, must be applied in all regions without exception. This definitely raised numerous difficulties and challenges. This study, therefore, attempts to illustrate the form and dynamics of development planning reform, identify the difficulties and challenges encountered, and provide input that may be considered in the efforts of achieving successful regional development planning reform in the future.

\section{Literature Review}

There are two different opinions regarding planning. Some view that planning merely deals with substance that is the achieved outcome, while others may see planning as merely relating to the process which is the method of achieving that outcome (Ferreira et al., 2009). This dichotomy of thoughts arises in planning practices and it results in two ideal types of plans, namely project plans and strategic plans (Faludi, 2000), the former relates to the level of conformance to the plans being carried out, while the latter relates to whether the existing plans improve performance. Rationally, it may be understood that the ends determine the means, while conversely the means determine the success in achieving the ends, it is thus equally important to consider the two types in plan reform. Development planning reform should, therefore, cover both means and ends.

Development is a planned social change directed at certain improvement standards 
(Pieterse, 2010). The area selected for reform mostly imitates or is inspired from the experiences of developed countries or the success of developing ones. The options are very broad and they are available within a series of development paradigms such as modernization (Rapley, 2007), world system and dependency (Preston, 1996), growth and equality (Todaro \&Smith, 2011), poverty (Yunus, 1999; Prahalad, 2004), people-centered (Korten, 1984) and freedom-centered development (Sen, 1999), capacity building and empowerment (Friedman, 1992; Eade, 1997), sustainability (Redclift, 1994; Atkinson et al., 2007), post development (Escobar, 2007; Kippler, 2010), and globalization (McMichael, 2012).

Planning reform in terms of process is mostly observed in the form of improvement in technical aspects, consistency, coherence, and coordination (Yagci \& Ardiani 2017), yet community participation is in most part widely demanded as it is more bottomup in nature and more responsive to the people's aspirations. Theoretically speaking, participation may take the artificial form of pseudo-participation and the genuine participation form which is cooperative and empowering (Deshler and Sock, 1985), and in composing the plan genuine participation is required. As of late, participation is inevitable as it is the rights of the people as citizens (Denhardt \& Denhardt, 2003). Nevertheless, the participation format should be aligned with local situation and conditions as people tend to have their own means of participating (Harper, 2003). Additionally, planning reform should be able to prevent misconducts of political elites and the bureaucracy in composing the plan since the plan itself relates to political interests (Baum, 1988). Principles of good governance are thus an essential requirement for more transparent and accountable planning.

One of the most popular forms of planning reform today is the implementation of strategic management and strategic planning in plan composition. The issue at hand would then be which paradigm or strategic management model is the best or most effective. In strategic management, there are four popular models (Joyce, 1999). The first model is classical planning, which is very much influenced by the classical management school, it tends to emphasize "compliance" to the constitution or existing legislations, logical framework, and it remains attentive to tasks and functions within the prevailing hierarchy. The second model is businesslike strategic planning, which is influenced by business management, it puts emphasis on initiatives, creativity, innovations, and entrepreneurship (imitating the business style) to increase productivity (output and outcome). The third model is visionary strategic planning, which highlights the vision of the institution's leader, and it emphasizes attractive aspirations/desires and the arduous strive to achieve them, yet it lacks consideration regarding the actual conditions and reality at hand. The fourth model is foresight-based strategic management, which is a model that foresees into the future by calculating past experiences, current conditions, various external and internal factors influencing the organization, considering "uncertainties" and various obstructing risks, and still paying attention to demands of the constitution, regulations, logic, innovation and more realistic vision.

The foresight-based model is considered to be the best as it covers the previous three models. In order to aptly apply the foresightbased paradigm, external and internal environmental analysis (David, 2011; Wheelen \& Hunger, 2012) and strategic issues analysis (Bryson, 2004) are required, and they will be utilized to compose strategies, policies and programs, or even revise existing vision and mission.

Development planning reform is surely unable to guarantee success lest followed by bureaucratic reform because bureaucracy is 
responsible or given the authority to compose planning documents. In this context, the role of the planner and the institution is of utmost importance since they are able to control "distorted communication" then direct it into "good design" and "right action" (Forester, 1994).

The explanation above provides the understanding that theoretically planning reform does not only include the means but the ends as well, and its success depends on external and internal factors of government bureaucracy.

\section{Methods}

This is a qualitative study that utilizes secondary data obtained from regulatory documents namely Law No. 25/2004, Permendagri 54/2010 and Permendagri 86/2017, and the latest Regional Mid-Term Development Plan (Rencana Pembangunan Jangka Menengah Daerah - RPJMD) documents acquired from Sleman, Kulon Progo, Bantul, Gunung Kidul Regencies, and Yogyakarta Municipality within the Province of Yogyakarta Special Region. Content analysis was employed to explore structures, forms, meanings, and practices of development planning reform written in those documents, it is subsequently combined with critical analysis of various relevant literature to illustrate the difficulties and challenges confronted in regional development planning reform.

This province was selected because it had on numerous occasions received national level awards and recognition in terms of development planning, implementation of good governance, and bureaucratic reform. The analysis result is not aimed at making generalizations as it is set to illustrate how development planning reform unfolds in a region that is identified to be among the best in Indonesia, for the purpose of gaining lessons learned in the implementation of development planning reform in the region.

\section{An Outlook on Development Planning Reform}

Development planning reform in Indonesia covers two aspects, namely reform of development goals and reform of methods employed in achieving those goals, of which are all written in a series of planning documents beginning from 1969 until today. Reform runs quite dynamically in line with the change in the regime of presidential leadership.

Development has been initiated in a planned and systematic manner since the New Order era which began with Suharto's reign as president of the Republic of Indonesia (RI) in 1969. The planning model implemented at the time can be categorized as classical planning wherein the program planning contents must comply to the Broad Outlines of the Nation's Direction (GarisGaris Besar Haluan Negara - GBHN) and the RI constitution. This model is centralized and topdown in nature, and it is stipulated in the Five Year Development Plan (Rencana Pembangunan Lima Tahun - REPELITA) document at the national level, which is subsequently translated into the Regional Five Year Development Plan (Rencana Pembangunan Lima Tahun Daerah REPELITADA) at the regional level. The focus of every REPELITA differed (Booth, 2005; Robinson, 2009), it began with development in the fields of agriculture, semi-finished industry, finished products, manufacture, and technology of which all were undertaken to increase export, growth, economic stability, and equality. Until Suharto's downfall in 1998, this centralized and top-down model remained dominant.

From 1999 to 2003, Indonesia had three consecutive presidents beginning with B.J. Habibie, then followed by Abdul Rachman Wahid, and Megawati, with a development orientation that lacked clarity due to domestic political instability. This period was dubbed as the transitional period to the Reform Order. Demands for decentralization and regional autonomy were constantly expressed and in 2001 under the leadership of President Abdul 
Rachman Wahid, regional autonomy was officially implemented. Development planning in this period had provided more latitude for implementing a bottom-up planning model as stipulated in the planning document of National Development Program (Program Pembangunan Nasional - PROPENAS). Planning during this period was more similar to businesslike planning because it maintained the development goals of creating market mechanism with healthy competition, growth paired with equality, quality of life, environmental preservation, fair employment opportunity, and protection of consumer's rights.

Under the administration of President Susilo Bambang Yudhoyono, who was democratically elected in 2004, development was reformed with pro-poor programs to address poverty issues, pro-job to overcome unemployment, pro-growth to enhance growth, and pro-sustainability to conserve environmental sustainability (Ananta et al., 2011). Since the period of Susilo Bambang Yudhoyono's administration, technocratic and centralized development planning was no longer considered adequate and it was replaced with a model that is more accommodating to the people's interests and strengthens community participation (Fuady, 2015). The publication of Law No. 25/2004 on the National Development Planning System is a significant momentum in development planning reform, including regional development planning.

Following the end of President Susilo Bambang Yudhoyono's two consecutive terms in 2014, Joko Widodo won the presidential election and began to focus his attention to the nine aspects of development planning, known as the NAWACITA program, which aims to enhance political stability and the maritime sector, improve governance, develop outlying villages/regions, alleviate poverty, reorganize land administration, improve the market, lower employment rate, increase quality of education, and health.
The development planning system during President Joko Widodo's administration remained the same with the one implemented during the President Susilo Bambang Yudhoyono era, as stipulated in Law No. 25/2004 with operational matters guided by the Permendagri No. 54/2010, which was then amended to Permendagri No. 86/2017.

According to the above regulations, development planning at the national level is specified in the National Long Term Development Plan (Rencana Pembangunan Jangka Panjang Nasional - RPJPN) for the next 20 years which subsequently guides the drafting of the National Mid-Term Development Plan (Rencana Pembangunan Jangka Menengah Nasional-RPJMN) for a period of 5 years. RPJMN is then clarified in the Government Work Plan (Rencana Kerja Pemerintah - RKP) which serves as a guideline in composing the yearly National Budget Plan (Rencana Anggaran dan Pendapatan Belanja Negara - RAPBN). All line ministries compose a Strategic Plan (Rencana Strategis Kementerian/ Lembaga-RENSTRA K/L) for a period of 5 years by referring to the RPJMN. This RENSTRA K/L then serves as a guideline in composing the line ministries' Work Plan(Rencana Kerja Kementerian/ Lembaga - RENJA K/L).

At the regional level (Province, Regency, and Municipality), a Regional Long Term Development Plan (Rencana Pembangunan Jangka Panjang Daerah-RPJPD) is composed for a period of 20 years by referring to the RPJPN. For regencies/municipalities in particular, the drafting of RPJPD must refer to the provincial RPJPD. The RPJPD then serves as a guideline for composing the Regional Mid Term Development Plan (Rencana Pembangunan Jangka Menengah Daerah - RPJMD) which is clarified in the Regional Government Work Plan (Rencana Kerja Pemerintah Daerah - RKPD) and subsequently referred to for drafting the Regional Budget Plan (Rencana Anggaran Pendapatan dan Belanja Daerah - RAPBD). RPJMD would also be referred to in composing 
the Strategic Plan of the Regional Level Working Unit (Rencana Strategis Satuan Kerja Perangkat Daerah - RENSTRA SKPD), which further serves as the guideline in drafting the Work Plan of the Regional Level Working Unit (Rencana Kerja Satuan Kerja Perangkat Daerah RENJA SKPD).

Given such development planning system and structure from central to regional level, it is expected that RAPBN, Provincial RAPBD, and Regional/Municipal RAPBD would be integrated, synchronized, and mutually synergic, without any duplication, mutual negation, or overlapping. The National Development Planning Agency (Badan Perencanaan Pembangunan Nasional BAPPENAS) is responsible for the composition of RPJPN, RPJMN, and RKP, while the Regional Development Planning Agency (Badan Perencanaan Pembangunan Daerah BAPPEDA) at the provincial and regional/ municipal levels are responsible for the composition of RPJPD, RPJMD, and RKPD respectively. In composing these planning documents, BAPPEDA conducts coordination, as well as synergizing and harmonizing efforts with Regional Units and stakeholders. The composition of RPJPD, RPJMD, and RKPD is done based on e-planning. The implementation of e-planning is regulated in the Ministerial Regulation. The Regional Units compose their respective regional RENSTRA and RENJA.

In composing the RENSTRA and RENJA of the Regional Units, they conduct coordination, as well as synergizing and harmonizing efforts with BAPPEDA and stakeholders. Composing the development plan in the current reform era is considered to be more accommodating of the people's needs and interests, and it has a composition flow that is more systematic, continuous, and applicative in accordance with the aspirations and participation of various elements in the country (Anggraini et al., 2015).

The same regulation also sets the other four structures of development planning reform. Firstly, the implementation of strategic planning, wherein the planning component must contain the vision and mission, goals, targets, strategies, policy direction, development priorities, programs, activities, performance and performance indicators. Secondly, the implementation of governance principles, wherein the composition of planning documents must adhere to the principles of good governance, which relates to being transparent, responsive, efficient, effective, accountable, participatory, measurable, fair, environmentally friendly, and sustainable.

Thirdly, the implementation of approach process, wherein the technocratic, participatory, political, top-down, and bottom-up approaches are used. The "technocratic" approach is employed in regional development planning by using scientific mind frame and methods to achieve the goals and targets of regional development. The "participatory" approach is employed by involving numerous stakeholders. The "political" approach is employed by translating the vision and mission of the elected Regional Head into the mid-term development planning document that is then discussed along with the Regional People's Representative Council (Dewan Perwakilan Rakyat Daerah - DPRD). The "top-down and bottom-up" approach refers to planning results that are aligned through development assemblies held starting from the Village, District, Regency/ Municipality, Province, and all the way to the Central government.

And fourthly, the implementation of interrelatedness approach, wherein development planning must apply three approaches, namely holistic-thematic, integrative, and spatial. The "holistic-thematic" approach in regional development planning is carried out by considering all development elements/sectors/activities as a single unit of factor with potentials, challenges, obstacles and/or problems that are interrelated between one another. The "integrative" approach is 
conducted by uniting several authorities into a single focused and integrated process with clarity in the efforts of achieving regional development goals. The "spatial" approach is carried out by considering the spatial dimension in planning.

\section{Issues and Challenges in Regional Development Planning Reform}

The scope of development planning reform to be discussed in the following is confined to in-depth analyses of RPJMD documents from the five regencies/ municipality in the Yogyakarta Province, which cover implementation of strategic planning, governance, process approach and interrelatedness.

Strategic Planning Implementation. Generally speaking, the strategic planning implementation of the Sleman, Kulon Progo, Bantul, Gunung Kidul regencies, and the Yogyakarta Municipality have adhered to the stipulations in the existing legislation. The elements of vision, mission, goals, targets, strategies, policy direction, development priorities, programs, activities, performance and performance indicators can entirely be found in the RPJMD documents. This is achieved because, aside from being required by Permendagri No. 54/2010 and Permendagri No. 86/2017, there are also consultations and disseminations from the staff of the Directorate General of Regional Development, Ministry of Home Affairs as well as mutual exchange of information among BAPPEDA personnel.

However, the interrelation and logic employed did not exactly follow the foresightbased paradigm and they rather prioritized the demand of classical planning paradigm that relies on "compliance" to regulatory provisions as its reference instead. When following the logic of the foresight-based paradigm, the main focus must be directed at external and internal environmental analyses prior to formulating strategic issues and strategies. Information data on potentials/opportunities, and threats/ challenges of external environment, and the strengths and weaknesses present in those five RPJMD documents were insufficient to formulate strategic issues and strategies. Although SWOT analysis was carried out, the data/information used were limited and lacked objectivity, and the analysis result was not much utilized as input for composing the following documents, particularly strategies, policy direction, programs, activities, priorities, performance and performance indicators. This indicates that the existing RPJMD only follows the normative demand of prevailing regulations (Permendagri 54/2010 or Permendagri 86/2017), and it is but a mere formality. The advantages of strategic planning have yet to be accommodated optimally in the RPJMD.

\section{Governance Implementation.} Governance implementation as a part of development planning reform seems to be inadequate. It was not elaborated in the five documents the methods and procedures that were truly applied in reality, instead there are normative explanations that are aligned with the requirement of the regulation. Materials on strategic issues, policy direction, programs, including priority programs in the five planning documents are not clarified regarding its origin or how they came to be. The transparency and accountability aspects have not been adequately satisfied, although this may be the caused by the document format not requiring them to do so.

However, there is a study on the level of Governance Index at the provincial level that may provide a rough illustration of the adoption of governance in the conduction of government affairs which shows that the position of Yogyakarta Province is rated the highest with excellent marks. The executive director of Partnership for Governance Reform, Wicaksono (2013), revealed the Indonesian Governance Index (IGI) results which classified the governance ranking of all the provinces in 
Indonesia. There was no province with an index score above 6.8 . Only 11, or approximately $33 \%$, provinces with index score between $6-6.8^{2}$, there were 17 provinces or $50 \%$ with IGI score between $5-6$, and there were 6 provinces or $18 \%$ that had index score below 5 . This data indicates that the majority or $68 \%$ of provinces in Indonesia still have yet to practice governance adequately. In other words, the practice of governance principles, namely participation, accountability, transparency, efficiency, effectiveness, and justice have yet to run properly in Indonesia.

The implementation of Governance principles is inseparable from the Bureaucratic Reform agenda in Indonesia. In 2011, a series of regulations were designed by the Ministry of Administrative and Bureaucratic Reform and the bureaucratic reform agenda was henceforth implemented in Indonesia. Yet, the result remains disheartening and this may be due to the fact that bureaucratic reform in Indonesia is carried out half-heartedly (McLeod, 2008). The Bureaucratic Reform Index evaluation conducted by the Minister of Administrative and Bureaucratic Reform in 2016 covered 8 areas of change, namely personnel mentality, monitoring, accountability, organizational matter, governance, human resources, legislation, and public service. The evaluation results show that there was no province that received an A score, only 2 provinces obtained BB score ${ }^{3}, 11$ provinces acquired B score, while 14 provinces received $\mathrm{CC}$ score and 7 provinces got $C$ (as processed from the Bureaucratic Reform Index Data, Ministry of Administrative and Bureaucratic Reform, 2016). In other words, the majority of provinces, or 21 of them to be exact, are still in dire need of improvement. Based on the above study, the implementation of Governance and Bureaucratic Reform in the

\footnotetext{
2 The Province of Yogyakarta Special Region obtained the highest score of 6.8.

${ }^{3}$ The Province of Yogyakarta obtained the highest assessment score of $\mathrm{BB}$ meaning excellent.
}

Province of Yogyakarta is indeed running well, although it remains suboptimal.

\section{Process Approach Implementation.}

It is not easy to implement technocratic, participatory, political, top-down and bottomup approaches in composing RPJMD. The technocratic approach requires the BAPPEDA personnel to possess proper capacity truly capable of utilizing data and information then process them in accordance to scientific principles. It must be admitted that the activities and program recommendations in the RPJMD of the five regencies/municipality were not based on clear and sufficient data/ information. Numerous calculations relating to performance indicators were not feasible due to data unavailability. This is worsened with the fact that BAPPEDA personnel are frequently transferred or experience post rotation, resulting in the new personnel lacking understanding of composing RPJMD.

Participatory approach is also easy to say but difficult to realize. The community's participation in the process of composing RPJMD indeed seemed to be a mere formality with the attendance of the invited participants, yet they did not actively propose their ideas, suggestions, or inputs concerning the RPJMD material. The level of social participation has not witnessed a significant increase in spite of the fact that the opportunity for more active participation in the reform era has been extensively provided (Widianingsih \& Morrell, 2007). In general, Indonesians have yet to participate actively. Even the regional governments remain reluctant to communicate their policies and development plans transparently to the public, citizens are thus unaware and unable to fully participate in the process of drafting government policies and plans, and if there were claims of participation, they are merely expressed to gain legitimacy from the people (Fuady, 2015).

The implementation of bottom-up approach also did not go very well. There is a 
tendency of the approach used to be dominated by a top-down one, particularly given that the region's fiscal capacity remains low and their reliance to the central government remains high in determining development programs in the region such as through the General Allocation Fund, the Special Allocation Fund, and so forth. This can be observed in the regional fiscal capacity map issued by the Ministry of Finance in 2017 via the Republic of Indonesia Minister of Finance Regulation No. 119/PMK.07/2017. Out of the 34 provinces only 9 or $26 \%$ were assessed to have high and very high fiscal capacity, 8 or $23.4 \%$ were categorized as moderate, and 17 provinces or $50 \%$ were specified as low and very low. Such fiscal capacity restricts the regional governments' latitude in determining their programs and budget according to their needs. As a result, the top-down planning approach remains dominant.

The political approach is directed at interpreting the vision and mission of the elected Regent/Mayor into the mid-term development planning documents that is to be discussed with the DPRD. This approach often prompts problems even conflicts since what had been promised during the Regent/ Mayor election campaign must be realized in the RPJMD programs. Meanwhile, a hearing with the DPRD is required and there is no guarantee that the DPRD would agree to the proposed programs for a particular reason. This often leads to budget misuse wherein the DPRD demands a certain fee for agreeing to the Regent/Mayor's proposal.

Interrelatedness Approach. RPJMD should apply a holistic-thematic, integrative, and spatial approach. In accordance with existing regulation, RPJMD is required to vertically interrelate vision and mission, which is by observing the interrelation with

${ }^{4}$ Yogyakarta's Fiscal Capacity Index score was identified as low at 0.51 , while the highest score went to Jakarta SCR at 7.87 and the lowest score went to Gorontalo Province at 0.23 . the top such as the vision of the province or the vision of the president, this also applies horizontally or spatially, which is by observing interrelation of vision to the surrounding regencies or municipalities that are socially and economically directly related (border areas). Interrelations with the existing General Spatial Plan of the Area should also be considered so there is no conflict over the use of land space that has been determined in the legislation. Close examination of the RPJMD from the five regencies/municipality shows that interrelation of the vision and mission were properly clarified in Chapter 5 on Vision and Mission, and the interrelation with the General Spatial Plan of the Area is also mentioned in Chapter 1 , which is in line with the existing regulatory instructions. However, in terms of establishing programs, it still seemed unclear, for instance through the regional partnership program. Perhaps the Regional Governments does not consider regional partnership as an urgency or of significant value. While in fact, cross-border socio-economic interactions heavily influence the dynamics of social, economic, and even political issues at the regional level, and this reality is accommodated in Law No. 23/2014 on Regional Government in the form of obligatory or elective partnership/collaboration.

Interrelation of time is also a very significant factor to consider. For instance, in the Bantul and Gunung Kidul Regencies, the targets and issues written in the RPJMD 5 years ago were actually evaluated and became inputs for composing the current RPJMD. Interrelations between the central, provincial, and regional/municipal governments are frequently discussed in the Development Coordination Meetings as inputs in composing RPJMD.

Based on the content analyses of the RPJMD documents from the five regencies/ municipality, it can thus be concluded as follows. First, the documents did not explain the process and dynamics of the actual drafting 
process, but it described what is required by the legislation. Additionally, it was not elaborated why those particular vision, mission, goals, targets, policy direction, and programs were proposed instead of others. This is why transparency and accountability as substantial elements in development planning reform remain overlooked. Second, the report format including the data and information needed were very thorough and rigidly arranged in the attachment of the regulation, and it was strictly followed by the five regencies/municipality, unfortunately the interrelation between the chapters still lacked clarity. For that reason, the interrelatedness element that requires integration, synchronization, and coordination remains problematic. Third, participation of stakeholders was not described in the RPJMD documents of the five regencies/municipality because there was in fact no explanation on the decision-making mechanism concerning programs and strategy recommendations. And fourth, the existing laws and regulation require the use of strategic planning in the RPJMD documents. Unfortunately, environmental analysis and identification of strategic issues have not been fully used to create strategies and programs, it even seemed to be a mere formality.

Due to such poor planning process in the RPJMD of these regencies/municipality, planning reform in terms of ends becomes less responsive to the needs of local residents. Thus, planning reforms turn to be a potential problem rather than a solution for regional development issues.

\section{Challenges in Regional Development Planning Reform}

A country with a high level of diversity such as Indonesia encounters numerous challenges that empirically and logically disrupt the implementation of planning reform. These challenges are complex and difficult to overcome as they do not only relate to technical aspects but geographical, socio-cultural, economic, and political as well.

Decentralization vs. Regional Government Capacity. People in the regions had great expectations in the advent of administrative decentralization including regional development planning. Unfortunately, their expectations were not entirely realized (Buehler, 2010), there are even "small kings" rising in the regions (Firman, 2009) who can disrupt the activities of regional governments including regional development planning. Discrepancies in development continue to occur since some of the more capable regions have obtained the opportunity to progress faster after being granted more authority and power from the central government, whereas some underdeveloped regions remain left behind (Holzhacker et al., 2016). It can indeed be objectively observed that quite a lot of regional governments lack the necessary capacity to implement planning reform. Bureaucratic reform, particularly that relating to the capacity of planning institution, human resources, DPRD support, and all Regional Level Work Units, has yet to provide satisfying results. Without the support of sufficient regional capacity, decentralization's demand to engage in planning reform will continue to be problematic.

Domination of the Legislative vs. the Vulnerability of the Executive. Given the current regulation, there seems to be a strong shift in the role of the legislative supported by political parties. With the position of the regional executive head being recommended and elected by the political parties, the budget and plan recommendations are frequently amended and aligned to the interests of political elites and parties. The legislative members in fact prioritizes their political party's interests rather than the people they represent (Salang, 2006). Furthermore, governors, regents, and mayors, who mostly come from political parties, or during the regional head election 
they were nominated by political parties, are given the authority via the Law on State Civil Apparatus (ASN) to serve as the Top Official for Personnel Administration in the region. This opens up a huge opportunity to decide the promotion and posting of ASNs in the region according to his/her desire or based on the intervention of political parties. This sets off acts of gratification and the buying and selling of government positions by bureaucrats with funding taken from the Regional Budget. Such position also has the potential to influence the Regional Secretary to insert particular programs and activities into the development planning documents according to their will or the instruction of political parties. As a result, there are inconsistencies between the RPJMD and the planning documents follow as were the cases found in Jakarta and South Bengkulu (Elitrisiana 2016; Afriani et al. 2015). Currently, the situation in numerous regional governments has become less conducive since executive officers feel threatened as their position and fate are easily intervened by political elites via the regional head who comes from a political party or is supported by one.

Corruption vs. Quality of Plan. Corruption has become a highly popular phenomenon in Indonesia and it always adorns the news on Indonesian social media. A pessimistic tone regarding corruption in Indonesia was expressed by Natasha (2001) two decades ago and it was assumed to continue expanding from the central government to all the regions in Indonesia, involving officials in the executive, legislative, and even judicial branch (Kristiansen et al., 2008). Given the prevailing political conditions, it seems that local political elites compete in amassing power by conducting corruption to defeat their political enemies (Tomsa, 2015).

Since the implementation of regional autonomy, which includes decentralization of development planning issues, corruption including collusion, nepotism, gratification, and abuse of authority have been occurring on a massive scale throughout all the regions in Indonesia, and only a few had been uncovered. The Indonesian Forum for Budget Transparency also known as "Fitra"" (2012) revealed that corruption has occurred evenly throughout 33 provinces, starting from the largest cases in the Province of Jakarta SCR (IDR 721 billion), Aceh (IDR 669 billion), North Sumatera (IDR 515 billion), Papua (IDR 476 billion), West Kalimantan (IDR 289 billion) until the smallest in the Province of Bali (IDR 6 billion), Yogyakarta (IDR 4 billion), and Bangka Belitung (IDR 1.9 billion).

Many political and bureaucratic elites manipulated the budget and plan recommendations in the Regional Budget through both formal and informal means. Most of them were regents/mayors involved individually or collectively in various types of corruption such as embezzlement, bribery, misprocurement, and favoritism (Silitonga et al., 2016). This phenomenon mostly relates to the manipulation of regional development budget allocation and plan recommendations. Corruption has been known to begin since the budget planning stage (Sucipto, 2015) and it tends to involve family and friends from regional elites (Silitonga et al., 2016). The corruption case in the Province of Banten, Indonesia involving the family of the governor and party dominance in the planning of vital projects (Hamid, 2014) is one of its actual examples. Development planning serves as a fertile ground for corruption.

The problems and difficulties confronted by regencies/municipality in the Province of Yogyakarta SR in implementing planning reform seems to be inseparable from the dilemma and challenges that have been described above. It is, hence, essential to conduct a review of the prevailing regulatory contents that take into consideration the locus variations where regional development planning reform is implemented. 


\section{Conclusion}

Given the situation and conditions elaborated above, it seems difficult to successfully implement development planning reform in terms of means and ends. Planning, which should be a solution, has become a problem instead due to the regional government's lack of capacity, failure in implementing principles of good governance in bureaucratic reform, and strong interventions and influences of political elites' interests in the region that utilize budget and planning documents for corrupt purposes. For those reasons, the following recommendations are presented: improvement of regional capacity, bureaucratic reform, implementation of good governance principles, and suppress corruption. Nevertheless, the key in overcoming those obstacles lie in the affirmative policy of enhancing regional capacity, and in the regional head and DPRD as the bearer of the highest authority in the region. There is also a need to review regulations that relate to political party dominance and the position of regional head as a political official and as a top official of personnel administration.

\section{References}

Afriani, A. N., Ketut, S., \& Roosemarina, A. R. (2015). Evaluasi perencanaan pembangunan dalam penentuan sektor unggulan di Kabupaten Bengkulu Selatan. Jurnal Ekonomi dan Perencanaan Pembangunan, 5(1), 14-26.

Ananta, A., Muljana, S., \& Sjamsul, A. (2011). The Indonesian economy: Entering a New Era. Jakarta: Bank Indonesia.

Angraini Y., Yasir, A., \& Rildwan, Z. (2015). Comparison of National Development Planning Before and After Amandment of Constitution 1945. Fiat Justisia Jurnal Ilmu Hukum, 9(1), $74-88$.

Atkinson, G., Dietz, S., Neumayer, E. (2007). Handbook of sustainable development. Northhampton: Edward Elgar Publishing, Inc
Baum, H. S. (1988). Planning theory as political practice. Society, 26, 35- 42.

Booth, A. (2005). The evolving role of the central government in economic planning and policy making in Indonesia. Bulletin of Indonesian Economic Studies, 41(2), 197-219.

Bryson J. M.(2004). Strategic planning for nonprofit organizations: A guide to strengthening and sustaining organizational achievement. San Fransisco, CA: John Wiley \& Sons.

Buehler, M. (2010). Decentralization and local democracy in Indonesia: the marginalization of the public sphere. In E. Aspinall \& M. Mietzner (Eds.), Problem of democatization in Indonesia: Elections, institutions and society, (pp. 267-87). Singapore: Institute of Southeast Asian Studies.

Cribb, R., \& Ford, M. (2009). Indonesia as an archipelagic: Managing Island, Managing Seas. In Indonesia beyond the Water's Edge: Managing an Archipelagic State. Singapore: Institute of Southeast Asian Studies.

Dalal-Cayton, B., Dent, D., \& Dubois, O. (2003). Rural Planning in developing countries: supporting natural resources management and sustainable livelihoods. London: International Institute for Environment and Development with Earthscan Publication.

David, F. R. (2011). Strategic management: Concept and cases (Thirteenth Edition). Upper Saddle River, New Jersey: Prentice Hall.

Denhardt, J.V., \& Denhardt, R. B. (2003). The new public service: serving not steering. New York: M. E. Sharpe.

Deshler, D., \& Sock, D. (1985). Community development participation: A review of the international literature. New York: Department of Education, Cornell University.

Eade, D. (1997). Capacity building: An approach to people centered development. UK: Oxfam GB.

Elitrisiana, M. R.Y. (2016). Konsistensi Program Rencana Pembangunan Jangka Menengah Daerah Tahun 2013 - 2017 dengan Anggaran 
Pendapatan dan Belanja Daerah di Provinsi DKI Jakarta: Studi Kasus Perencanaan Program dan Anggaran pada Urusan Wajib Dasar Bidang Kesehatan dan Sosial Tahun 2015. Jurnal Pembangunan Daerah, IV(1), 1-28.

Escobar, A. (2007). 'Post-development' as concept and social practice. In A. Ziai (Eds.), Exploring Post-development: Theory and practice, problems and perspectives (pp.18-31). London: Routledge.

Faludi, A. (2000). The performance of spatial planning. Planning Practice and Research, 15(4), 299-318.

Ferreira, A., Sykes, O., \& Batey, P. (2009). Planning theory or planning theories? The hydra model and its implications for planning education. Journal for Education in the Built Environment, 4(2), 29-54.

Firman, T. 2009. Decentralization reform and local-government proliferation in Indonesia: Toward a fragmentation of regional development. Review of Urban and Regional Development Studies, 21, 143-157.

Fitriani, F., Hofman, B., \& Kaiser, K. 2005. Unity in Diversity? The creation of new local governments in a decentralizaton Indonesia. Bulletin of Indonesian Economic Studies, 41 (1), 57-79.

Forester, John. 1994. Critical Theory, Public Policy and Planning Practice. Albany, NY: State University of New York Press.

Forester, John. 1999. The Deliberative Practitioner: Encouraging Participatory Planning Processes. London: MIT Press

Forshee, Jill. 2006. Culture and Customs of Indonesia. Westport CT: Greenwood Press.

Forum Indonesia Untuk Transparansi Anggaran (Fitra). (2012). Peringkat Provinsi Terkorup di Indonesia. Retrieved May 25, 2018 from https://m.detik.com/news/berita/2047460/ ini-dia-peringkat-provinsi-terkorup-diIndonesia-versi-fitra.

Friedman, J. (1992). Empowerment: the politics of alternative development. Cambridge, USA: Blackwell Publishers.
Fuady, A. H. (2015). Perencanaan pembangunan di Indonesia pasca Orde Baru: Refleksi tentang penguatan partisipasi masyarakat. Masyarakat Indonesia, 38(2), 376 - 397.

Hamid, A. (2014). A family matter: Political corruption in Banten, Indonesia. Asian Politics \& Policy, 6(4), 577-593.

Harper, C. (2003). The power in participatory practice. In D. Potts, P. Ryan \& A. Toner (Eds.), Development Planning and Poverty Reduction (pp. 45-67). New York: Palgrave Mac Millan

Hill, H., \& Vidyattama, Y. (2014). Hares and tortoises: Regional development dynamics in Indonesia. In H. Hill (Eds.), Regional Dynamics in a Decentralized Indonesia. Singapore: Institute of Southeast Asian Studies.

Holzhacker, R. L., Wittek, R., Woltjer, J. (2016). Decentralization and Governance for Sustainable Society in Indonesia. In R.L.Holzhacker, R.Wittek, \& J.Woltjer (Eds.), Decentralization and Governance in Indonesia. Switzerland: Springer International Publishing.

Joyce, P. (1999). Strategic management for the public services: Managing the public services. Philadelphia: Open University Press.

Kippler, C. (2010). Exploring Post-Development: Politics, the State and Emancipation. The question of alternatives. POLIS Journal, 3, 1-38.

Korten, D. C. (1984). People-centered development: Toward a framework. In D.C.Korten \& R. Klaus (Eds.), People Centered Development: Contributions towards theory and planning framework. West Hartford, Conn: Kumarian Press.

Kristiansen, S., Dwiyanto A., Pramusinto A., \& Putranto, E.A. (2008). Public Sector Reforms and financial transparency: Experience from Indonesia Districts. Contemporary Southeast Asia, 31(1), $64-87$

McLeod, R. H. (2008). Indequate budgets and salaries as instruments for institutionalizing 
public sector corruption in Indonesia. South East Asia Research, 16(2), 199-223.

McMichael, P. (2012). Development and social change: A global perspective (Fifth Edition). Thousand Oak, CA: Sage Publication.

Natasha, H. H. (2001). Anti-Corruption Strategies in Indonesia. Buletin of Indonesian Economic Studies, 37(1), 65-82.

Pieterse, J. N. (2010). Development theory: Deconstructions/reconstructions(Second Edition). Los Angeles, CA: Sage Publicatios Ltd.

Potts, D., Ryan, P., \& Toner, A. (2003). Poverty and Planning. In D. Potts, P. Ryan, \& A Toner (Eds.), Development Planning and Poverty Reduction (Pp. 1-9). New York: Palgrave Mac Millan.

Prahalad, C.K. (2004). The Fortune at the Bottom of the Pyramid. New Jersey: Prentice-Hall.

Preston, P.W. (1996). Development theory. Cambridge: Blackwell Publishers Inc.

Ranis, G. \& Stewart, F. (1994). Decentralization in Indonesia. Bulletin of Indonesian Economic Studies, 30(3), 41-72.

Rapley, J. (2007). Understanding Development: theory and practice in the Third World. Boulder COL.: Lynne Riener Publishers, Inc.

Redclift, M. (1994). Strategies for sustainable development: local agendas for the South. In M. Redclift \& C. Sage (Eds.). New York: John Eiley Sons Ltd.

Robinson, R. (2009). Indonesia: the rise of capital. Kuala Lumpur: Equinox Publishing.

Salang, S. (2006). Parlemen: Antara kepentingan politik vs aspirasi rakyat. Jurnal Konstitusi, 3(4), 90-120.

Wicaksono, S. (2013). Peringkat "Indonesia Governance Index". Retrieved May 24, 2018 from https://nasional.kompas.com/ $\mathrm{read} / 2013 / 09 / 02 / 1414357 /$ Ini-PeringkatIndonesia-Governance-Index-2012.

Sen, A. (1999). Development as freedom. New York: Anchor Brook.
Silitonga, M. S., Anthonio G., Heyse, L., \& Wittek, R. (2016). Decentralization and Governance in Indonesia. In Holzhacker, Ronald L., Wittek, Rafael, Woltjer, Johan (Eds.). Switzerland: Springer International Publishing.

Sucipto, Y. (2015). Korupsi (sudah) Terjadi Sejak Perencanaan Anggaran. Retrieved May 24, 2018 from http://info-anggaran. com/2015/03/16/korupsi-sudah-terjadisejak-perencanaan-anggaran/.

Suwondo, K. (2002). Decentralization in Indonesia. International Non-Government Organization Forum on Indonesian Development (INFID).

Todaro, M. P., \& Smith, S. C. (2011). Pembangunan Ekonomi (11 ${ }^{\text {th }}$ edition). Jakarta: Penerbit Erlangga.

Tomsa, D. (2015). Local Politics and Corruption in Indonesia's Outer Islands. Bijdragen Tot De Taal, Land -En Volkenkunde, 171, 196-219. Turner, M., \& Hulme, D. (1997). Planning for development: The solution or the problem?. (Governance, Administration and Development: making the state work). London: MacMillan Press LTD.

Wheelen, T. L, \& Hunger, J. D. (2012). Strategic management and business policy. Upper Saddle River, New Jersey: Pearson Education Inc. Widianingsih, I., \& Morrell, E. (2007). Participatory Planning in Indonesia. Policy Studies, 28(1), 1-15.

Yagci, M., \& Natasha, A. (2017). National Development Planning, Industrial Policy, and Sustainable Growth Challenges in Indonesia and Malaysia: A comparative Historical Analysis. In M. Yulek (Eds.), Industrial Policy and Sustainable Growth, Sustainable Development. Singapore: Springer Nature Singapore Pte Ltd.

Yunus, M. (1999). Banker to the poor: Microlending and the battle against world poverty. New York: Public Affair. 